\title{
PEMODELAN PETA MATERIALITAS INFORMASI PADA LAPORAN KEBERLANJUTAN PERUSAHAAN (Suatu Tinjauan Mengenai Pelaporan Keberlanjutan Industri Perbankan di Indonesia)
}

\author{
Putu Sukma Kurniawan \\ Universitas Pendidikan Ganesha, Singaraja, Indonesia \\ putusukma1989@gmail.com
}

\begin{abstract}
Corporate sustainability report has become a new paradigm in the evolution of corporate reporting. Corporate sustainability report is a form of corporate management responsibility to all of the stakeholders. This study aims to create a map of information materiality contained in the sustainability report of the banking industry in Indonesia.The method used is analyze content of sustainability reports of the banking industry in Indonesia. Data collection is done by looking for secondary data through page of Indonesia Stock Exchange or company official website. Data analysis was done descriptively by analyzing the contents of sustainability report. The analysis is done by comparing the contents of the sustainability report with the disclosure items contained in the GRI G4 reporting standard (Fourth Generation of Global Reporting Initiative), especially in GRI G4 Sector Disclosures Financial Services. The results of this study produce maps containing material information in the sustainability report of the banking industry. The results of this study may contribute to the management of the company to identify the material information that can be submitted to the company's stakeholders.
\end{abstract}

Keywords: Map of Information Materiality, Sustainability Reporting, Sustainability Report, Banking Industry

\begin{abstract}
ABSTRAK
Laporan keberlanjutan perusahaan kini menjadi paradigma baru dalam evolusi pelaporan. Laporan keberlanjutan perusahaan merupakan bentuk tanggung jawab manajemen perusahaan kepada seluruh pemangku kepentingan perusahaan. Penelitian ini bertujuan untuk membuat sebuah peta materialitas informasi yang terdapat pada laporan keberlanjutan industri perbankan di Indonesia. Metode yang dipergunakan adalah dengan melakukan analisis konten dari laporan keberlanjutan industri perbankan yang ada di Indonesia. Teknik pengumpulan data dilakukan dengan mencari data sekunder melalui laman Bursa Efek Indonesia maupun laman resmi perusahaan. Analisis data dilakukan secara deskriptif dengan melakukan analisis isi laporan keberlanjutan. Analisis dilakukan dengan membandingkan isi laporan keberlanjutan dengan item-item pengungkapan yang terdapat pada standar pelaporan GRI G4 (Global Reporting Initiative Generasi Keempat), khususnya pada GRI G4 Sector Disclosures Financial Services. Hasil dari penelitian ini menghasilkan peta yang berisi informasi material dalam laporan keberlanjutan industri perbankan. Hasil penelitian ini dapat memberikan kontribusi bagi manajemen perusahaan untuk melakukan identifikasi mengenai informasi material yang dapat disampaikan pada pemangku kepentingan perusahaan.
\end{abstract}

Kata Kunci: Peta Materialitas Informasi, Pelaporan Kebelanjutan, Laporan Keberlanjutan, Industri Perbankan 


\section{Pendahuluan}

Laporan keberlanjutan (sustainability report) kini menjadi paradigma baru dalam proses pelaporan perusahaan. Laporan keberlanjutan menjadi ujung dari proses evolusi pelaporan perusahaan. Pada awalnya proses pelaporan perusahaan masih berfokus pada laporan keuangan yang memuat angka-angka keuangan. Kinerja perusahaan masih didasarkan pada angka-angka keuangan. Paradigma saat ini beranggapan bahwa angkaangka keuangan yang dihasilkan oleh perusahaan belum menjamin kinerja perusahaan secara komprehensif. Seiring dengan perkembangan dalam dunia bisnis, kini manajemen perusahaan dituntut untuk melaksanakan konsep keberlanjutan dalam menjalankan aktivitas bisnis perusahaan. Konsep keberlanjutan dapat diartikan bahwa manajemen perusahaan dalam menjalankan aktivitas bisnis perusahaan harus pula memikirkan dampak-dampak lain yang dapat diakibatkan oleh aktivitas bisnis perusahaan tersebut. Dalam hal ini termasuk juga dampak sosial dan lingkungan yang dapat muncul. Berdasarkan konsep keberlanjutan ini, maka kinerja perusahaan agar lebih dapat dinilai secara komprehensif dapat dinilai dari kinerja ekonomi, kinerja sosial, dan kinerja lingkungan.

Laporan keberlanjutan perusahaan secara garis besar mengandung informasiinformasi mengenai kinerja ekonomi, kinerja sosial, dan kinerja lingkungan perusahaan. Tentu saja informasi yang disajikan dalam laporan keberlanjutan perusahaan merupakan informasi yang merepresentasikan kondisi perusahaan ditinjau dari sudut pandang konsep keberlanjutan. Secara umum manajemen perusahaan menyusun laporan keberlanjutan perusahaan didasarkan pada standar GRI (Global Reporting Initiative) yang saat ini telah masuk ke standar GRI G4 (GRI Generasi Keempat). Brown et. al., (2009) menyatakan bahwa kerangka kerja GRI merupakan kerangka kerja yang komprehensif yang dipergunakan untuk pelaporan kinerja sosial dan kinerja lingkungan dari perusahaan. Ini merupakan sebuah standar baku untuk pelaporan sukarela perusahaan dalam bidang sosial dan lingkungan. Pada standar GRI terdapat item-item pengungkapan yang dapat dijadikan pedoman bagi manajemen perusahaan dalam menyusun sebuah laporan keberlanjutan perusahaan. Pada konsep pelaporan perusahaan terdapat konsep materialitas (konsep materialitas informasi). Zhou (2011) berpendapat bahwa pada awalnya konsep materialitas berkembang pada konteks pelaporan keuangan perusahaan (financial reporting) dan saat ini telah diaplikasikan pada konsep pelaporan keberlanjutan perusahaan. Konsep materialitas informasi pada konsep pelaporan keberlanjutan perusahaan akan membuat manajemen perusahaan untuk mengidentifikasi, menyeleksi, dan memfokuskan isu-isu keberlanjutan yang memiliki dampak signifikan pada aktivitas bisnis perusahaan.

Alasan penelitian ini mengambil topik pada laporan keberlanjutan industri perbankan dan berfokus pada materialitas informasi pada laporan keberlanjutan perusahaan didasarkan pada beberapa hal, yaitu (1) Beberapa literatur menjelaskan bahwa pelaporan keberlanjutan dikeluarkan oleh industri-industri yang basis operasi bisnisnya dapat merusak lingkungan. Industri perbankan aktivitas bisnisnya cenderung tidak merusak alam dan lingkungan, namun pada kenyataannya kelompok industri perbankan turut pula mengeluarkan laporan keberlanjutan. Hal ini menjadi menarik untuk membahas pelaporan keberlanjutan dari sudut pandang industri perbankan. (2) Laporan keberlanjutan mencakup tiga hal utama, yaitu kinerja ekonomi, kinerja sosial, dan kinerja lingkungan. Dalam konteks ini sangat penting untuk membahas kinerja sosial dan kinerja lingkungan industri perbankan kemudian membandingkannya dengan kinerja sosial dan kinerja lingkungan pada industri-industri yang "dikatakan" dapat 
merusak lingkungan, misalnya industri manufaktur. (3) Materialitas informasi sangat penting untuk diketahui agar kita dapat menyajikan informasi-informasi yang memang diperlukan oleh pemangku kepentingan, yang dalam hal ini adalah pemangku kepentingan dalam industri perbankan. Informasi-informasi yang bersifat material akan sangat membantu seluruh pemangku kepentingan perusahaan dalam mengambil keputusan bisnis dan keputusan lainnya. Latar belakang lain yang mendasari penulis mengambil topik pada materialitas informasi pada laporan keberlanjutan perusahaan adalah merujuk penelitian yang dilakukan oleh GRI (Global Reporting Initiative) dan RobecoSAM pada tahun 2015 yang meneliti mengenai materialitas informasi dan dampaknya pada manajemen perusahaan dan investor (GRI, 2015). Hasil penelitian GRI \& RobecoSAM (2015) memberikan manfaat untuk memperkuat proses pelaporan keberlanjutan perusahaan. Manfaat lain adalah kita dapat memperkirakan dampak yang dapat ditimbulkan dari aktivitas bisnis perusahaan baik kepada pemangku kepentingan internal maupun pemangku kepentingan eksternal perusahaan. Fokus penelitian ini adalah untuk memberikan pemahaman baru mengenai informasi yang bersifat materialitas pada laporan keberlanjutan perusahaan. Dalam membantu untuk mencapai fokus penelitian ini, maka akan dilakukan analisis yang mendalam pada laporan keberlanjutan industri perbankan di Indonesia. Rumusan masalah dalam penelitian ini yang juga bertujuan untuk mendukung fokus penelitian, yaitu bagaimana pemodelan peta materialitas infomasi pada laporan keberlanjutan perusahaan, khususnya pada indutri perbankan? Fokus penelitian ini adalah menyusun sebuah model peta materialitas informasi khususnya dalam laporan keberlanjutan industri perbankan. Fokus penelitian ini juga didasarkan pada hasil penelitian GRI dan RobecoSAM pada tahun 2015 yang menyatakan bahwa pada industri perbankan dan sektor keuangan, terdapat empat isu (informasi) utama yang bersifat material yang menjadi perhatian dari investor perusahaan. Empat isu utama tersebut adalah risk management (manajemen resiko), corporate governance (tata kelola perusahaan), human capital management (manajemen sumber daya manusia), dan business ethic (etika bisnis). Penelitian ini akan mencoba untuk menemukan informasi yang bersifat material dalam industri perbankan di Indonesia dan membandingkannya dengan hasil penelitian GRI dan RobecoSAM tahun 2015.

Penulisan artikel ini bertujuan untuk memberikan gambaran mengenai informasi yang bersifat material dalam pelaporan keberlanjutan di Indonesia, khususnya informasi material dalam laporan keberlanjutan industri perbankan di Indonesia.Artikel ini diharapkan dapat memberikan kontribusi bagi perkembangan proses pelaporan keberlanjutan di Indonesia. Penulis menyadari bahwa secara global telah terjadi perkembangan yang sangat signifikan dalam proses pelaporan keberlanjutan perusahaan. Telah banyak manajemen perusahaan yang menyadari pentingnya proses pelaporan keberlanjutan perusahaan. Brown et. al., (2009) menyatakan bahwa salah satu alasan manajemen perusahaan melakukan pelaporan keberlanjutan adalah untuk menjaga reputasi manajemen dan perlindungan terhadap merk perusahaan. Meskipun secara teoretis alasan manajemen perusahaan seharusnya murni merupakan tanggung jawab sosial perusahaan untuk mengeluarkan laporan keberlanjutan. Motivasi manajemen perusahaan dalam mengeluarkan laporan keberlanjutan dapat dinilai pula dari informasi-informasi yang disajikan dalam laporan keberlanjutan. Jika manajemen perusahaan menyajikan informasi yang benar-benar diperlukan oleh pemangku kepentingan perusahaan, maka motivasi manajemen memang benar untuk memberikan informasi yang komprehensif kepada pemangku kepentingan, bukan sekadar untuk 
meningkatkan citra perusahaan saja. Implikasi penelitian ini diharapkan dapat memberikan pemahaman kepada manajemen perusahaan mengenai informasi yang bersifat material dalam laporan keberlanjutan perusahaan, khususnya dalam industri perbankan. Hasil penelitian dapat pula memberikan manfaat kepada calon investor dimana para calon investor dapat melakukan penilaian yang lebih komprehensif pada perusahaan dengan tidak hanya melihat informasi material dalam kinerja ekonomi perusahaan, namun dapat pula mempertimbangkan informasi material dalam kinerja sosial dan kinerja lingkungan perusahaan. Diharapkan nantinya akan didapatkan pemahaman yang baru mengenai informasi-informasi material dalam laporan keberlanjutan industri perbankan di Indonesia. Model peta materialitas informasi dalam laporan keberlanjutan ini diharapkan dapat memberikan pemahaman mengenai informasi-informasi manakah yang relevan dan berdampak signifikan pada kinerja perusahaan dan seluruh pemangku kepentingan perusahaan dalam industri perbankan di Indonesia.

\section{Tinjauan Literatur}

\section{Teori Enterprise}

Soetedjo (2009) menyatakan bahwa terdapat tiga teori dalam konteks sudut pandang akuntansi. Tiga teori tersebut adalah teori kepemilikan (proprietary theory), teori entitas (entity theory), dan teori enterprise (enterprise theory). Konsep akuntansi pada awalnya menganut teori kepemilikan dan teori entitas. Teori kepemilikan berpendapat bahwa prosedur pencatatan akuntansi harus berpusat pada kepentingan pemilik perusahaan dan teori entitas menjelaskan bahwa akuntansi dipergunakan untuk mencatat kondisi ekonomi perusahaan serta bentuk pertanggungjawaban manajemen dalam pengelolaan perusahaan (Soetedjo, 2009). Dalam perkembangannya paradigma bisnis saat ini mengalami perubahan dimana telah berkembang sudut pandang dari sisi teori enterprise. Teori enterprise memandang bahwa fungi perusahaan bukan hanya alat bagi pemilik perusahaan untuk meningkatkan kekayaan, namun juga dipergunakan untuk kepentingan eksternal lingkungan yang dalam hal ini adalah sisi sosial dan lingkungan alam. Teori enterprise menjelaskan bahwa akuntansi dipergunakan untuk mencapai kemakmuran sosial (Soetedjo, 2009). Dalam konteks pelaporan keberlanjutan, manajemen perusahaan tidak hanya menyediakan informasi yang penting bagi pihak internal perusahaan namun juga menyediakan informasi penting bagi pihak di eksternal perusahaan. Dengan disediakannya semua informasi material untuk pemangku kepentingan perusahaan, maka pertanggungjawaban manajemen akan menjadi lebih luas dan lebih objektif. Pelaporan keberlanjutan juga penting untuk meningkatkan legitimasi perusahaan di masyarakat. Retno \& Priantinah (2012) menyatakan bahwa manajemen perusahaan akan mendapat legitimasi yang kuat dalam menjalankan aktivitas bisnis jika memiliki keberpihakan pada komunitas sosial dan lingkungan.

\section{Informasi Material pada Laporan Keberlanjutan Perusahaan}

Laporan keberlanjutan (sustainability report) dapat didefinisikan sebagai sebuah laporan yang berisikan kinerja ekonomi, kinerja sosial, dan kinerja lingkungan dari perusahaan. Konsep dari penyusunan sebuah laporan keberlanjutan adalah konsep keberlanjutan (sustainability concept). Konsep keberlanjutan menjelaskan bahwa perusahaan harus turut memberikan kontribusi bagi alam dan masyarakat sehingga alam 
ini dapat dimanfaatkan bagi keberlangsungan generasi berikutnya. Dengan kata lain kita dapat memahami bahwa konsep keberlanjutan dapat diartikan sebagai "apa kontribusi manajemen perusahaan terhadap komunitas sosial dan lingkungan yang berada di sekitar perusahaan" dan "bagaimana manajemen perusahaan memikirkan solusi dari dampak yang ditimbulkan oleh aktivitas bisnis perusahaan terhadap komunitas sosial dan lingkungan di sekitar perusahaan." Secara langsung konsep keberlanjutan "memaksa" manajemen perusahaan untuk ikut memikirkan dampak dari aktivitas bisnis perusahaan dan manajemen perusahaan harus memberikan kontribusi kepada komunitas sosial dan lingkungan yang berada di sekitar perusahaan. Konsep triple bottom lines dapat memberikan pemahaman kepada manajemen bahwa perusahaan harus melakukan analisis mengenai dampak aktivitas perusahaan terhadap komunitas sosial dan lingkungan (Nuryaman, 2013). Konsep keberlanjutan dan triple bottom lines inilah yang menjadi salah satu dasar dalam akuntansi sosial dan lingkungan. Qureshi et. al. (2012) menyatakan bahwa akuntansi sosial dan lingkungan muncul karena adanya perhatian yang lebih luas untuk melihat kinerja sosial dan kinerja lingkungan perusahaan.

Informasi yang material dalam laporan keberlanjutan perusahaan dapat diartikan sebagai informasi-informasi yang relevan dan berdampak signifikan pada organisasi (perusahaan) dan pemangku kepentingan perusahaan. Sebuah informasi dikatakan bersifat material bila informasi tersebut dapat mempengaruhi keputusan, aksi, dan kinerja dari organisasi (perusahaan) dan pemangku kepentingan perusahaan. Pedoman dalam standar GRI menyatakan bahwa "the information in a report should cover topics and indicators that reflect the organization's significant economic, environmental, and social impacts or that would substantively influence the assessments and decisions of stakeholders."Berdasarkan pada standar GRI dapat dipahami pengertian dari materialitas informasi bahwa informasi-informasi yang terdapat dalam laporan keberlanjutan perusahaan harus dapat menggambarkan dampak dari aktivitas bisnis perusahaan atau informasi-informasi tersebut dapat mempengaruhi keputusan dari pemangku kepentingan perusahaan. Secara sederhana identifikasi informasi yang bersifat material bertujuan untuk melakukan identifikasi masalah internal dan eksternal perusahaan yang pada masa depan dapat menimbulkan resiko bisnis perusahaan dan identifikasi informasi yang menjadi perhatian seluruh pemangku kepentingan perusahaan. Analisis mengenai materialitas ini sangat berguna bagi manajemen perusahaan untuk menentukan strategi keberlanjutan yang tepat bagi bisnis perusahaan dan nantinya dapat menghasilkan laporan keberlanjutan yang berkualitas bagi seluruh pemangku kepentingan perusahaan.

Informasi yang bersifat material ini tentu saja harus disajikan oleh manajemen perusahaan di dalam laporan keberlanjutan perusahaan. Manajemen perusahaan harus dapat menentukan informasi-informasi mana saja yang relevan bagi perusahaan dan bagi seluruh pemangku kepentingan perusahaan. Hal ini disebabkan karena informasi yang bersifat material sangat berpengaruh terhadap perusahaan dan utamanya pada pengambilan keputusan yang dilakukan oleh pemangku kepentingan perusahaan. Brown et. al., (2009) berpendapat bahwa salah satu cara agar informasi pada laporan keberlanjutan dapat memberikan dampak yang besar adalah sektor keuangan (pasar modal) harus dapat memberikan perhatian yang lebih pada informasi non finansial. Hasil penelitian Brownet. al., (2009) menunjukkan bahwa investor institusional memberikan perhatian yang masih sedikit terhadap data-data kinerja non finansial perusahan. Hal yang meggembirakan tentu saja adalah saat ini telah muncul banyak indeks di pasar modal yang menggunakan konsep keberlanjutan. Munculnya indeks- 
indeks pada pasar modal yang berbasiskan konsep keberlanjutan seperti Dow Jones Sustainability Index turut berperan pada peningkatan penggunaan informasi pada laporan keberlanjutan. Dengan melakukan analisis secara mendalam terhadap kinerja keberlanjutan perusahaan (kinerja ekonomi, kinerja sosial, dan kinerja lingkungan), investor dapat memperoleh pemahaman yang lebih baik mengenai kualitas manajemen dan potensi kinerja perusahaan di masa depan. Proses ini akan berujung pada kemampuan investor untuk melakukan identifikasi dan taksiran terhadap nilai investasi di masa depan. Tentu saja kualitas informasi pada laporan keberlanjutan perusahaan akan menentukan kualitas keputusan investasi yang akan dibuat oleh investor. Laporan Ernst \& Young (2015) menyampaikan bahwa 83\% perusahaan dalam SGX top 50 melaporkan aspek-aspek sustainabilitas (keberlanjutan) sebagai informasi yang material bagi perusahaan dan $63 \%$ dari perusahaan-perusahaan tersebut memberikan bukti bagaimana cara untuk mengidentifikasi isu-isu keberlanjutan tersebut. Hasil penelitian Khan et. al., (2016) menyatakan bahwa perusahaan-perusahaan yang memiliki tingkat pengungkapan yang baik dalam isu-isu keberlanjutan memiliki kinerja atau performa di pasar modal yang lebih baik dibandingkan dengan perusahaan dengan tingkat pengungkapan isu keberlanjutan yang rendah. Fakta ini menunjukkan bahwa manajemen perusahaan telah menyadari pentingnya informasi terkait isu keberlanjutan dalam pengambilan keputusan oleh investor dan investor pun telah merespon isu-isu keberlanjutan yang telah diungkapkan oleh manajemen perusahaan.

\section{Pelaporan Keberlanjutan Industri Perbankan Secara Global dan di Indonesia}

Pelaporan keberlanjutan kini telah diaplikasikan pada semua industri, termasuk pula pada industri perbankan. Secara global tren pelaporan keberlanjutan semakin meningkat. Hasil laporan Ernst \& Young (2015) mengungkapkan bahwa 80\% perusahaan yang terdapat dalam SGX top 50 mencantumkan beberapa item terkait dengan sustainabilitas dalam laporan tahunan perusahaan atau di dalam laman resmi perusahaan dan $60 \%$ perusahaan dalam SGX top 50 melaporkan kinerja keberlanjutannya.Secara umum tren pelaporan keberlanjutan di Indonesia, khususnya pula dalam industri perbankan semakin naik. Ini dibuktikan dengan banyaknya perusahaan di Indonesia yang mulai menyusun laporan keberlanjutannya dan kemudian memublikasikan laporan keberlanjutan tersebut kepada seluruh pemangku kepentingan perusahaan. Salah satu bukti lainnya adalah adanya kategori industri perbankan dalam kompetisi Indonesia Sustainability Reporting Award (ISRA) yang telah dilaksanakan. Brown et. al., (2009) berpendapat bahwa tren pelaporan keberlanjutan perusahaan diikuti dengan perluasan informasi yang disampaikan pada laporan keberlanjutan perusahaan dimana informasi saat ini telah mencakup perluasan pada dampak sosial dari aktivitas bisnis perusahaan, peningkatan informasi untuk pemegang saham dan karyawan, dan integrasi antara konsep keberlanjutan dengan informasi keuangan. Pendapat menarik dikemukakan oleh Sangle (2010) yang berpendapat bahwa manajemen perusahaan akan cenderung melaporkan informasi sosial dan lingkungan bila kompetitor mereka dalam industri yang sama ikut melaporkan informasi sosial dan lingkungan. Hal ini yang juga menjadi alasan tren perkembangan pelaporan keberlanjutan perusahaan. Kolk (2008) berpendapat bahwa tren pelaporan keberlanjutan dalam semua industri berhubungan dengan tata kelola perusahaan (corporate governance). Pengungkapan informasi non finansial dalam laporan keberlanjutan dapat dipahami sebagai sebuah akuntabilitas manajemen kepada pemangku kepentingan 
perusahaan. Tren pelaporan keberlanjutan dalam industri perbankan dapat dilihat pula dari aspek etika dimana manajemen harus mengungkapan informasi-informasi non finansial untuk menunjukkan keberlanjutan perusahaan dalam industri.

\section{Metode Penelitian}

Desain penelitian ini merupakan penelitian yang mencoba untuk mendapatkan pemahaman baru mengenai proses pelaporan keberlanjutan. Desain penelitian atau metode penelitian ini menggunakan desain analisis dokumen (documentary analysis). Dalam konteks ini maka penelitian ini mendalami sebuah pemahaman dari isi dokumen laporan keberlanjutan perusahaan. Metode penelitian ini sejalan dengan penelitian yang dilakukan oleh Naraduhita \& Sawarjuwono (2012) yang mempergunakan teknik analisis isi (content analysis). Teknik analisis ini dapat dipergunakan ketika akan dilakukan pemahaman mengenai isi dari sebuah laporan yang dalam hal ini adalah laporan keberlanjutan perusahaan. Terlebih dahulu akan dilakukan proses analisis untuk mengidentifikasi informasi-informasi yang material dalam laporan keberlanjutan dan selanjutnya disusun peta materialitas informasinya. Objek penelitian ini adalah pelaporan keberlanjutan industri perbankan di Indonesia. Sampel yang dipergunakan dalam penelitian ini adalah laporan keberlanjutan yang telah dipublikasikan oleh perusahaan-perusahaan yang tergabung dalam industri perbankan, utamanya perbankan yang mengikuti kompetisi Indonesia Sustainability Reporting Award (ISRA) pada tahun 2014, 2015, dan 2016. Kompetisi ISRA merupakan sebuah kompetisi penilaian laporan keberlanjutan perusahaan yang diselenggarakan oleh National Center for Sustainability Reporting (NCSR). Dasar dipergunakannya laporan keberlanjutan industri perbankan yang mengikuti kompetisi ISRA adalah asumsi bahwa laporan-laporan keberlanjutan perusahaan yang mengikuti kompetisi ISRA lebih lengkap dan proses seleksi dalam kompetisi telah menunjukkan kualitas dari laporan keberlanjutan yang dihasilkan oleh manajemen perusahaan. Berdasarkan data yang terdapat pada laman resmi ISRA diperoleh informasi mengenai perusahaan dalam industri perbankan yang menjuarai kompetisi ISRA. Perusahaan-perusahaan inilah yang laporan keberlanjutannya akan dianalisis dalam penelitian ini. Berdasarkan laman resmi ISRA maka pada tahun 2014 yang menjadi pemenang adalah (1) PT Bank Negara Indonesia (Persero) Tbk, (2) PT Bank Danamon Indonesia Tbk, dan (3) PT Bank CIMB Niaga. Pada tahun 2015 yang menjadi pemenang SRA dalam kategori industri perbankan adalah (1) PT Bank Negara Indonesia (Persero) Tbk, (2) PT Bank Danamon Indonesia Tbk, dan (3) PT Bank Maybank Indonesia Tbk. Pada tahun 2016 yang menjadi pemenang SRA dalam kategori industri perbankan adalah (1) PT Bank Negara Indonesia (Persero) Tbk, (2) PT Bank Danamon Indonesia Tbk, dan (3) BPD Central Java (Bank BPD Jawa Tengah).

Teknik pengumpulan data dilakukan dengan mencari data sekunder melalui laman Bursa Efek Indonesia maupun laman resmi perusahaan. Melalui laman resmi Bursa Efek Indonesia dan laman resmi perusahaan akan diunduh laporan keberlanjutan selama 3 (tiga tahun) berturut-turut, yaitu dari tahun 2014 sampai tahun 2016. Jika hanya terdapat 1 (satu) laporan keberlanjutan selama kurun waktu tahun 2014 sampai tahun 2016, akan tetap dipergunakan sebagai sampel. Hal ini dilakukan semata-mata agar pembahasan yang dilakukan dapat lebih mendalam dan komprehensif. Berdasarkan data sekunder yang diperoleh, maka sampel laporan keberlanjutan dalam penelitian ini, yaitu 


\begin{tabular}{|c|c|c|}
\hline No & Nama Perusahaan & Sampel Laporan Keberlanjutan \\
\hline \multirow[t]{3}{*}{1} & \multirow{3}{*}{$\begin{array}{l}\text { PT Bank Negara Indonesia } \\
\text { (Persero) Tbk }\end{array}$} & Laporan Keberlanjutan Tahun 2014 \\
\hline & & Laporan Keberlanjutan Tahun 2015 \\
\hline & & Laporan Keberlanjutan Tahun 2016 \\
\hline \multirow[t]{2}{*}{2} & \multirow[t]{2}{*}{ PT Bank Danamon Indonesia Tbk } & Laporan Keberlanjutan Tahun 2014 \\
\hline & & Laporan Keberlanjutan Tahun 2015 \\
\hline \multirow[t]{3}{*}{3} & \multirow[t]{3}{*}{ PT Bank CIMB Niaga } & Laporan Keberlanjutan Tahun 2014 \\
\hline & & Laporan Keberlanjutan Tahun 2015 \\
\hline & & Laporan Keberlanjutan Tahun 2016 \\
\hline \multirow[t]{2}{*}{4} & \multirow[t]{2}{*}{ PT Bank Maybank Indonesia Tbk } & Laporan Keberlanjutan Tahun 2014 \\
\hline & & Laporan Keberlanjutan Tahun 2015 \\
\hline \multirow[t]{3}{*}{5} & \multirow[t]{3}{*}{ Bank BPD Jawa Tengah } & Laporan Keberlanjutan Tahun 2014 \\
\hline & & Laporan Keberlanjutan Tahun 2015 \\
\hline & & Laporan Keberlanjutan Tahun 2016 \\
\hline
\end{tabular}

Berdasarkan sampel laporan keberlanjutan, maka terdapat 13 (tiga belas) laporan keberlanjutan yang akan dianalisis. Analisis data dilakukan secara deskriptif dengan melakukan analisis isi laporan keberlanjutan. Analisis dilakukan dengan membandingkan isi laporan keberlanjutan dengan item-item pengungkapan yang terdapat pada standar pelaporan GRI G4 (Global Reporting Initiative Generasi Keempat), khususnya GRI G4 untuk industri perbankan. Pada standar pelaporan GRI G4, standar pelaporan untuk industri perbankan disebut dengan GRI G4 Sector Disclosures Financial Services.

\section{Analisis Data dan Pembahasan}

\section{Proses Identifikasi Informasi yang Bersifat Material}

Informasi yang bersifat material dalam laporan keberlanjutan perusahaan dapat diartikan sebagai informasi-informasi yang dapat mempengaruhi keputusan manajemen perusahaan dan pemangku kepentingan perusahaan. Informasi yang bersifat material sangat ditentukan oleh karakteristik perusahaan, karakteristik industri, dan karakteristik dari pemangku kepentingan perusahaan. Terdapat langkah-langkah yang dapat dipergunakan untuk menentukan atau mengidentifikasi informasi-informasi yang bersifat material yang akan disajikan dalam laporan keberlanjutan perusahaan, seperti yang tertulis dalam pedoman AA1000APS. Pedoman AA1000APS merupakan sebuah pedoman mengenai konsep keberlanjutan perusahaan yang dikeluarkan oleh lembaga AccountAbility dari Inggris. Dalam pedoman AA1000APS terdapat tiga prinsip dalam keberlanjutan perusahaan, yaitu prinsip inklusivitas, prinsip materialitas, dan prinsip responsivitas. Langkah-langkah dalam menentukan atau mengidentifikasi informasi yang bersifat material dalam laporan keberlanjutan perusahaan adalah:

1. Mengidentifikasi isu-isu penting yang berkembang dalam konteks aktivitas bisnis perusahaan

Dalam tahap ini sangat penting untuk melakukan identifikasi terhadap isuisu yang penting dalam aktivitas bisnis perusahaan. Identifikasi isu-isu penting ini merupakan langkah awal untuk menentukan informasiimformasi mana saja yang bersifat material.

2. Mengevaluasi tingkat relevansi isu-isu tersebut dengan keberlanjutan perusahaan 
Langkah berikutnya adalah dengan melakukan evaluasi atau penilaian apakah isu-isu yang telah diidentifikasi tersebut relevan dan sesuai dalam konteks keberlanjutan perusahaan.

3. Menentukan tingkat signifikansi dari isu keberlanjutan yang telah teridentifikasi dengan menggunakan kriteria yang telah ditentukan

Langkah selanjutnya adalah dengan menentukan tingkat signifikansi (seberapa penting) isu-isu tersebut dalam konteks keberlanjutan perusahaan. Dalam langkah ini akan diketahui mana isu keberlanjutan yang memiliki tingkat signifikansi yang tinggi dan mana isu keberlanjutan yang memiliki tingkat signifikansi yang rendah.

4. Mengidentifikasi dampak-dampak dari isu-isu keberlanjutan perusahaan terhadap kepentingan dari seluruh pemangku kepentingan perusahaan

Pada tahap ini dilakukan identifikasi dampak apakah yang diterima oleh pemangku kepentingan perusahaan ditinjau dari isu-isu keberlanjutan perusahaan. Dampak-dampak yang diidentifikasi dapat berupa dampak positif maupun dampak yang negatif. Pembahasan ini akan menjadi sebuah rekomendasi bagi manajemen untuk dapat melaksanakan aktivitas bisnis perusahaan dalam konteks keberlanjutan dengan lebih baik lagi.

\section{Informasi yang Bersifat Material dalam Laporan Keberlanjutan Industri Perbankan}

Dalam tahap ini akan dilakukan identifikasi informasi-informasi yang bersifat material dalam laporan keberlanjutan perusahaan industri perbankan yang dijadikan sampel. Akan dilakukan analisis terhadap isi laporan keberlanjutan dari masing-masing perusahaan sampel. Berdasarkan GRI G4 Sector Diclosures Financial Services, secara umum terdapat dua jenis pelaporan, yaitu pelaporan umum (general standard disclosures) dan pelaporan khusus (specific standard disclosures). Pada setiap jenis pelaporan terdapat item-item pelaporan yang dapat dicantumkan pada laporan keberlanjutan industri perbankan. Pada pelaporan umum terdapat item-item pengungkapan, yaitu analisis dan strategi (strategy and analysis), profil organisasi (organizational profile), identifikasi aspek material (identified material aspects and boundaries), hubungan dengan pemangku kepentingan perusahaan (stakeholders engagement), tata kelola (governance), dan etika dan integritas (ethics and integrity). Pada pelaporan khusus dibedakan menjadi tiga jenis pengungkapan, yaitu pengungkapan aspek ekonomi, pengungkapan aspek lingkungan, dan pengungkapan aspek sosial. Untuk pengungkapan aspek sosial dibedakan menjadi beberapa sub kategori, yaitu praktek pekerja (labor practices), hak asasi manusia (human rights), sikap sosial (society), dan tanggung jawab produk (product responsibility). Pada tahap ini akan dilakukan analisis mengenai informasi yang bersifat material pada masingmasing laporan keberlanjutan yang dipergunakan sebagai sampel.

\section{A. Mengidentifikasi isu-isu penting yang berkembang dalam konteks aktivitas bisnis perusahaan \\ 1. Identifikasi Informasi Material pada Laporan Keberlanjutan PT Bank Negara Indonesia (Persero) Tbk}


Pada tahap ini dilakukan identifikasi terkait dengan laporan keberlanjutan PT Bank Negara Indonesia (Persero) Tbk tahun 2014, 2015, dan 2016. Laporan keberlanjutan PT BNI tahun 2014 dan tahun 2015 menggunakan kriteria GRI G4 Core. Pada laporan keberlanjutan PT BNI tahun 2014 telah dijelaskan bahwa penentuan isi laporan keberlanjutan telah didasarkan pada empat prinsip GRI G4, yaitu keterlibatan pemangku kepentingan, konteks keberlanjutan, materialitas, dan kelengkapan. Khusus untuk penentuan aspek materialitas, PT BNI menyelenggarakan workshop internal yang menghasilkan 7 aspek material. Untuk pengungkapan umum telah diungkapkan semua pada laporan keberlanjutan tahun 2014 dan tahun 2015. Berikut merupakan aspek material (pengungkapan khusus) yang diungkapkan dalam laporan keberlanjutan tahun 2014 dan tahun 2015, yaitu (1) nilai ekonomi, (2) dampak ekonomi tidak langsung, (3) konsumsi energi dan biodiversitas, (4) praktek ketenagakerjaan, (5) hak asasi manusia dan diskriminasi, (6) tanggung jawab produk, dan (7) anti-korupsi. Laporan keberlanjutan pada tahun 2016 menggunakan pendekatan GRI G4 Core. Pada laporan keberlanjutan tahun 2016 telah dibuatkan sebuah matriks yang berisikan mengenai informasi yang penting bagi perusahaan serta informasi yang penting pula bagi pemangku kepentingan perusahaan. Matriks yang berisikan mengenai informasi-informasi yang material disebut dengan matriks materialitas informasi. Matriks materialitas informasi pada laporan keberlanjutan tahun 2016 tersebut, yaitu

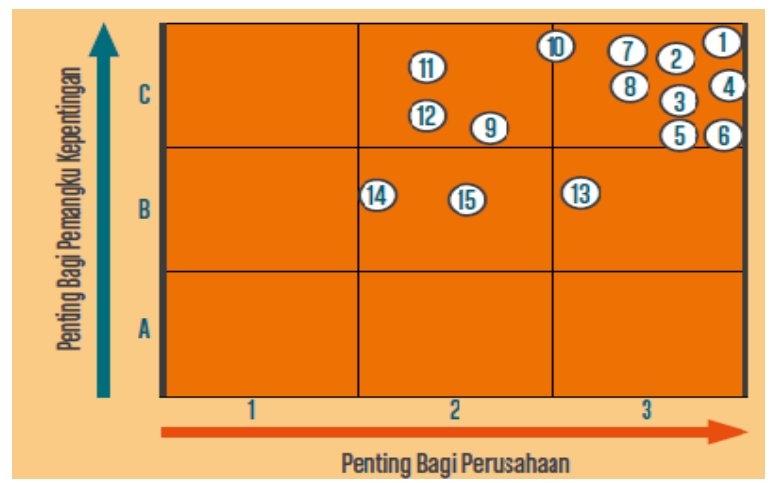

Gambar 1. Matriks materialitas informasi

Sumber: Laporan Keberlanjutan PT BNI (Persero) Tbk (2016)

Berdasarkan gambar 1 maka dapat dipahami bahwa manajemen PT BNI telah mengelompokkan informasi pada laporan keberlanjutan sesuai dengan tingkat materialitasnya. Pada gambar 1 maka informasi-informasi yang memiliki tingkat materialitas tinggi adalah informasi yang terdapat pada kuadran 3C, yaitu (1) kinerja ekonomi, (2) privasi pelanggan, (3) pemasaran dan pelabelan produk/jasa, (4) portofolio keuangan, (5) E-banking dan E-channel, (6) E-billing dan Estatement, (7) pendidikan dan pelatihan, (8) pembiayaan infrastruktur, dan (10) anti korupsi dan fraud. Informasi yang bersifat tidak material adalah informasi yang terdapat pada kuadran 2B, yaitu (14) green building, dan (15) kesehatan dan keselamatan kerja. 


\section{Identifikasi Informasi Material pada Laporan Keberlanjutan PT Bank Danamon Indonesia Tbk}

Pada tahap ini dilakukan analisis terhadap laporan keberlanjutan PT Bank Danamon Indonesia Tbk. Pada laporan keberlanjutan tahun 2015 dipergunakan pendekatan GRI G4 Core. Dalam melakukan pengkajian mengenai aspek material, manajemen telah melibatkan seluruh karyawan dan pemangku kepentingan perusahaan. Manajemen PT Bank Danamon Indonesia telah membuat matriks mengenai analisis materialitas. Matriks tersebut, yaitu

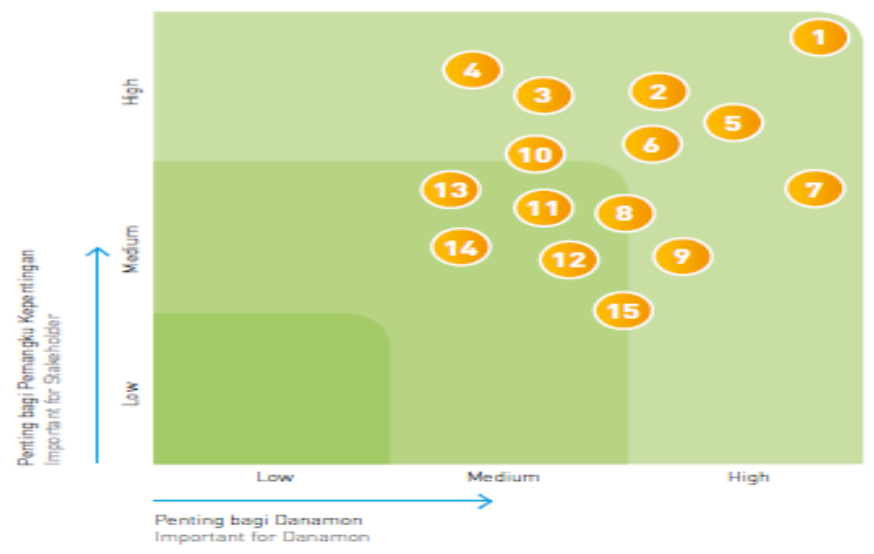

Gambar 2. Matriks materialitas informasi

Sumber: Laporan Keberlanjutan PT Bank Danamon Indonesia (2015)

Berdasarkan matriks materialitas informasi tersebut dapat dipahami bahwa informasi yang bersifat materialitas adalah informasi yang terdapat pada kuadran high dan high. Informasi tersebut, yaitu (1) akses ke layanan perbankan, (2) perbankan yang aman, (3) Informasi mengenai produk dan layanan, (4) anti korupsi dan anti fraud, (5) jasa keuangan untuk segmen mikro dan UKM, (6) penghormatan terhadap HAM, dan (7) pelatihan dan pengembangan karyawan.

\section{Identifikasi Informasi Material pada Laporan Keberlanjutan PT Bank CIMB Niaga}

Laporan keberlanjutan PT Bank CIMB Niaga tahun 2014 menggunakan pendekatan GRI G4 Core dan telah dijamin pula oleh penjamin independen. Adanya penjaminan dari pihak independen tentu saja dapat meningkatkan kredibilitas laporan keberlanjutan perusahaan. Manajemen PT Bank CIMB Niaga telah membuat matriks informasi materalitas untuk laporan keberlanjutan tahun 2014. Matriks informasi tersebut, yaitu 


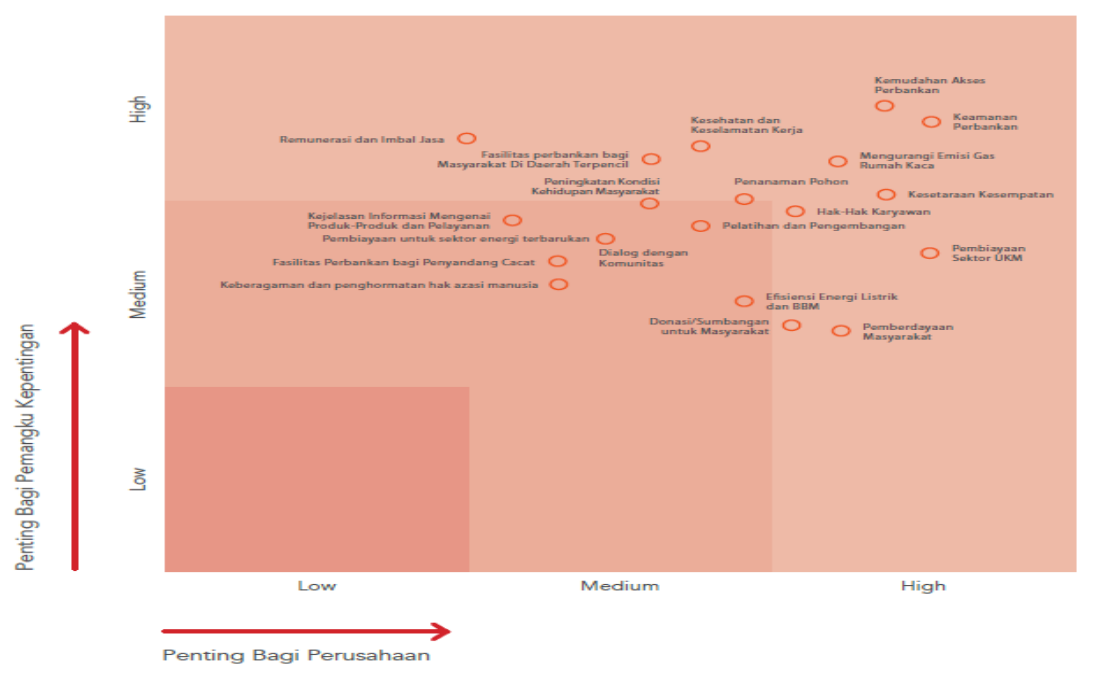

Gambar 3. Matriks materialitas informasi

Sumber: Laporan Keberlanjutan PT Bank CIMB Niaga (2014)

Berdasarkan gambar 3 maka dapat dipahami bahwa informasi materialitas terdapat pada kuadran high dan high. Informasi-informasi tersebut, yaitu kemudahan akses perbankan, keamanan perbankan, mengurangi emisi gas rumah kaca, kesetaraan kesempatan, kesehatan dan keselamatan kerja, penanaman pohon, dan hak-hak karyawan.

Laporan keberlanjutan PT Bank CIMB Niaga tahun 2016 masih menggunakan pendekatan GRI G4 Core. Manajemen PT Bank CIMB Niaga pada laporan keberlanjutan tahun 2016 telah membuat matriks materialitas informasi, yaitu

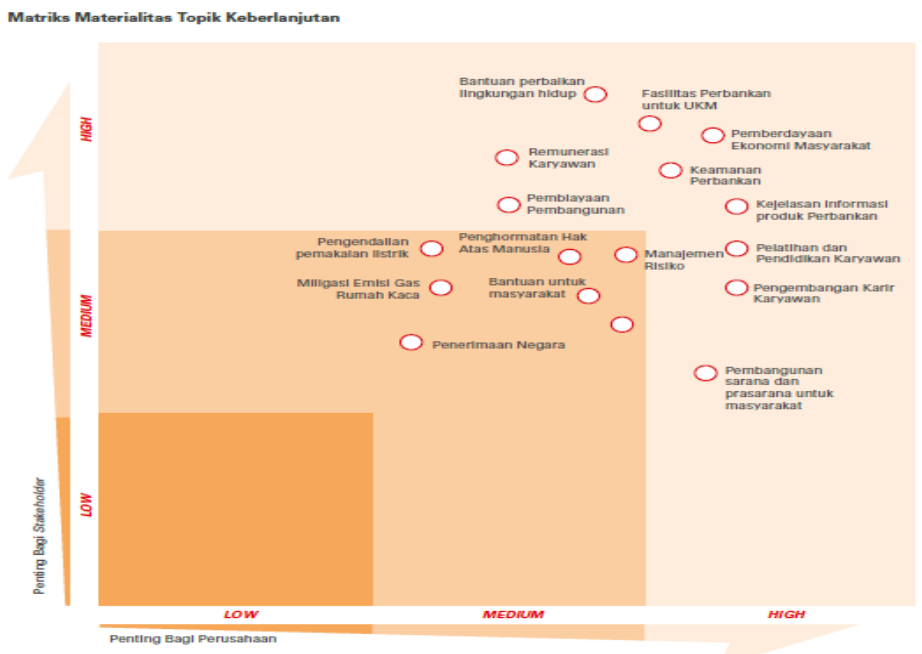

Gambar 4. Matriks materialitas informasi

Sumber: Laporan Keberlanjutan PT Bank CIMB Niaga (2016)

Berdasarkan gambar 4 maka dapat dilihat bahwa informasi yang bersifat materialitas terdapat pada kuadran high dan high. Informasi-informasi tersebut, yaitu fasilitas perbankan untuk UKM, pemberdayaan ekonomi masyarakat, keamanan perbankan, kejelasan informasi produk perbankan, dan pelatihan dan pendidikan karyawan. 


\section{Identifikasi Informasi Material pada Laporan Keberlanjutan PT Bank Maybank Indonesia Tbk}

Laporan keberlanjutan PT Bank Maybank Indonesia pada tahun 2014 mempergunakan pendekatan GRI G4 Core. Manajemen PT Bank Maybank Indonesia menyatakan bahwa belum terdapat pelibatan pemangku kepentingan dalam penentuan aspek-aspek material untuk laporan keberlanjutan tahun 2014. Pada laporan keberlanjutan tahun 2014 belum dibuatkan sebuah matriks materialitas informasi. Aspek-aspek material (pengungkapan khusus) dalam laporan keberlanjutan tahun 2014, yaitu (1) kinerja ekonomi, (2) dampak ekonomi tidak langsung, (3) keanekaragaman hayati, (4) emisi, (5) ketenagakerjaan, (2) kesehatan dan keselamatan kerja, (7) pelatihan dan pendidikan, (8) kebebasan berserikat, (9) anti korupsi, dan (10) masyarakat lokal. Laporan keberlanjutan PT Bank Maybank Indonesia pada tahun 2015 mempergunakan pendekatan GRI G4 Core. Pada laporan keberlanjutan tahun 2015 telah dijelaskan bahwa penentuan aspek materialitas didasarkan pada diskusi kelompok yang terfokus dan semua topik yang berkaitan dengan humanising financial services dimasukkan ke dalam topik yang bersifat material. Matriks materialitas informasi pada laporan keberlanjutan tahun 2015, yaitu

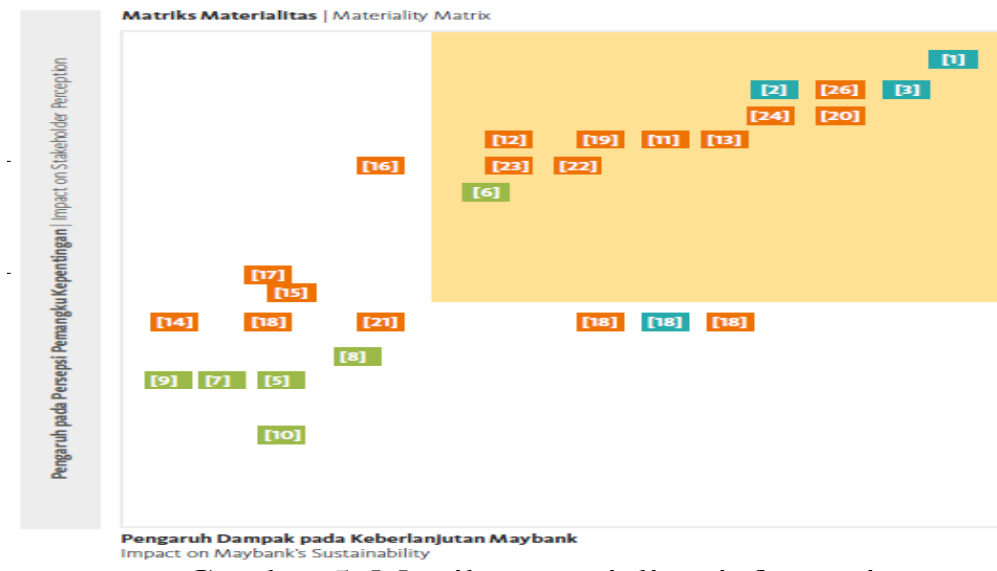

Gambar 5. Matriks materialitas informasi

Sumber: Laporan Keberlanjutan PT Bank Maybank Indonesia (2015)

Berdasarkan gambar 5 dapat diketahui bahwa informasi-informasi yang bersifat material pada laporan keberlanjutan tahun 2015 adalah (1) kinerja keuangan, (2) dampak ekonomi tidak langsung, (3) portofolio, (6) energi, (11) ketenagakerjaan, (12) kesehatan dan keselamatan kerja, (13) pendidikan dan pelatihan, (19) masyarakat setempat, (20) anti korupsi, (22) akses perbankan, (23) literasi perbankan, (24) pelabelan produk dan jasa, dan (26) privasi pelanggan.

\section{Identifikasi Informasi Material pada Laporan Keberlanjutan Bank BPD Jawa Tengah}

Tahap ini dilakukan analisis pada laporan keberlanjutan Bank BPD Jawa Tengah. Pada laporan keberlanjutan tahun 2014 pendekatan yang dipergunakan adalah pendekatan GRI G4 Core. Pada laporan keberlanjutan tahun 2014 telah disusun matriks materialitas informasi, yaitu 


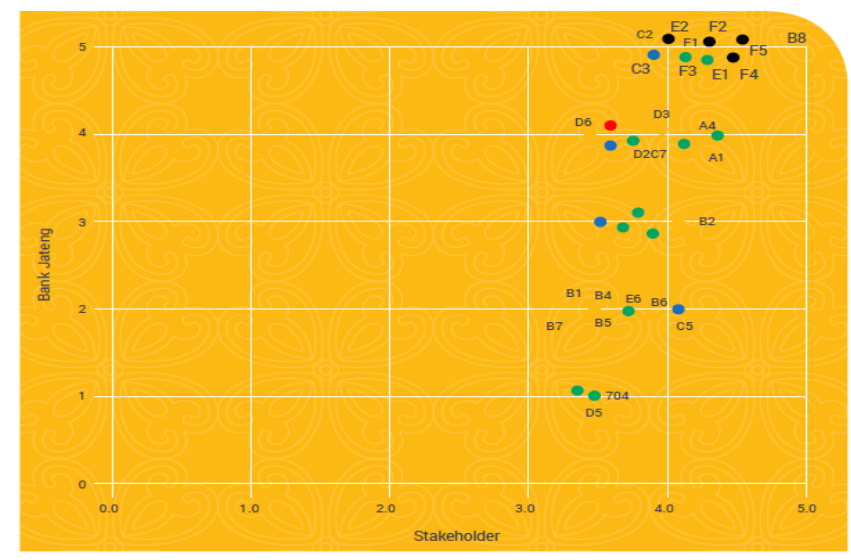

Gambar 6. Matriks materialitas informasi

Sumber: Laporan Keberlanjutan Bank BPD Jawa Tengah (2014)

Berdasarkan gambar 6 dapat dilihat bahwa informasi-informasi yang bersifat material adalah (F5) kepatuhan, (F4) privasi nasabah, (E1) pemberdayaan masyarakat, $(\mathrm{F} 2)$ pelabelan produk dan jasa, $(\mathrm{F} 1)$ kesehatan dan keselamatan, $(\mathrm{F} 3)$ komunikasi pemasaran, (E2) anti korupsi, (C2) keselamatan dan kesehatan, dan (C3) pelatihan dan pendidikan. Pada laporan keberlanjutan tahun 2015 masih mempergunakan pendekatan GRI G4 Core. Hal yang menarik dalam laporan keberlanjutan tahun 2015 adalah adanya definisi dari materialitas dari sisi manajemen dimana manajemen menjelaskan bahwa prinsip materialitas "mengutamakan pengungkapan informasi yang penting dan signifikan bagi pemangku kepentingan dan memiliki dampak penting pada kinerja keberlanjutan perusahaan." Manajemen pun telah melakukan pengelompokan terhadap aspek yang bersifat material ke dalam tiga tingkatan, yaitu high, medium, dan low. Matriks materialitas informasi untuk laporan keberlanjutan tahun 2015, yaitu

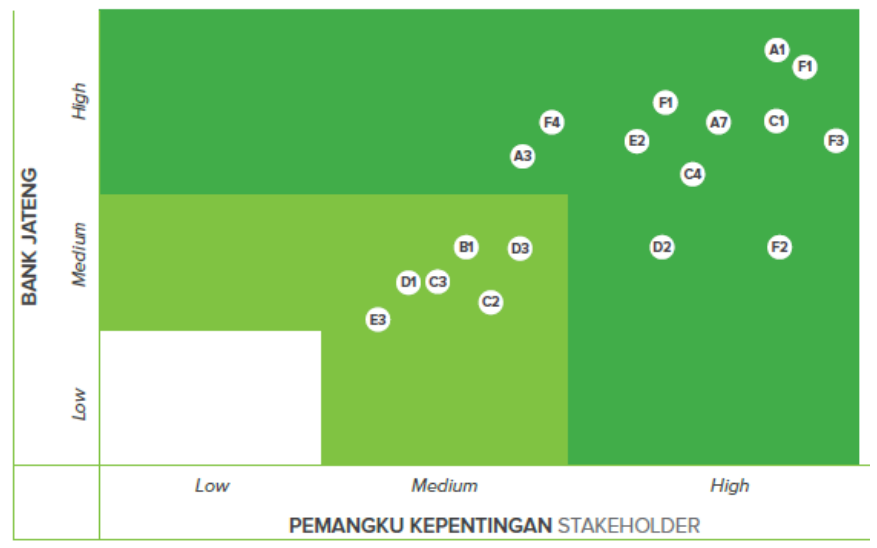

Gambar 7. Matriks materialitas informasi

Sumber: Laporan Keberlanjutan Bank BPD Jawa Tengah (2015)

Berdasarkan gambar 7 dapat dilihat bahwa informasi yang bersifat material terdapat pada kuadran high, yaitu (A1) kinerja ekonomi, (F1) pelabelan produk dan jasa, (C1) kepuasan pegawai, (F3) perlindungan privasi nasabah, (E2) komitmen anti korupsi, dan (C4) pelatihan dan pendidikan pegawai. Pada laporan keberlanjutan tahun 2016 pendekatan yang dipergunakan adalah GRI G4 Core. 
Manajemen dalam menyusun matriks materialitas laporan keberlanjutan tahun 2016 telah melakukan penilaian materialitas (materiality assessment). Matriks materialitas informasi untuk laporan keberlanjutan tahun 2016, yaitu

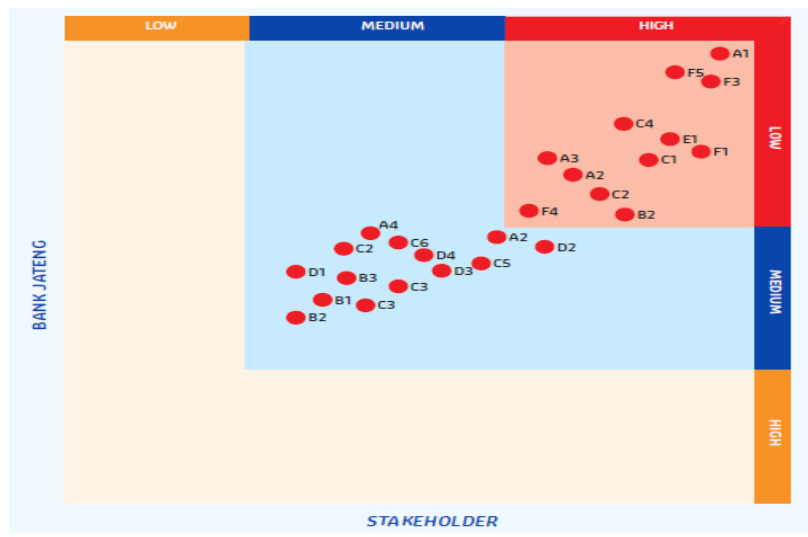

Gambar 8. Matriks materialitas informasi

Sumber: Laporan Keberlanjutan Bank BPD Jawa Tengah (2016)

Berdasarkan gambar 8 maka dapat diperoleh bahwa informasi yang material terdapat dalam kuadran high. Penulis memberikan sedikit perbaikan terkait dengan matrik materialitas pada gambar 8 dimana seharusnya pada kuadran yang berwarna merah tertulis high dan high, bukan high dan low. Terdapat 12 informasi yang bersifat material pada kuadran high, yaitu (A1) kinerja ekonomi, $(\mathrm{F} 3)$ perlindungan privasi nasabah, (F5) inklusi keuangan, (C4) pelatihan dan pendidikan, (E1) pemberdayaan masyarakat lokal, (F1) informasi produk dan jasa, (C1) kepegawaian, (A3) dampak ekonomi tidak langsung, (A2) rasio perbandingan gaji dengan upah minimum, (C2) hubungan industrial, (B2) penggunaan air, dan (F4) kepatuhan terhadap peraturan terkait dengan produk dan jasa.

\section{B. Mengevaluasi tingkat relevansi isu-isu tersebut dengan keberlanjutan perusahaan}

Secara umum dapat dikatakan bahwa informasi-informasi material yang telah disusun dalam matriks materialitas relevan dengan keberlanjutan perusahaan. Seluruh informasi yang bersifat material yang disampaikan oleh manajemen perusahaan telah mencakup kinerja ekonomi, kinerja sosial, dan kinerja lingkungan. Pada beberapa laporan keberlanjutan yang dipergunakan sebagai sampel, manajemen persuahaan mengungkapkan bahwa penentuan aspek-aspek materialitas yang akan dicantumkan dalam laporan keberlanjutan perusahaan telah disesuaikan dengan konsep keberlanjutan perusahaan di masa yang akan datang. Informasi mengenai energi dan penggunaan sumber daya air relevan dengan kebijakan lingkungan pada industri perbankan. Hampir semua laporan keberlanjutan perusahaan sampel telah menyebutkan persentase penggunaan kertas, energi, dan sumber daya air. Informasi mengenai pengembangan karir dan pelatihan bagi pegawai telah relevan dengan konsep keberlanjutan perusahaan. Manajemen perusahaan dalam menyusun laporan keberlanjutannya telah berpedoman pada GRI G4 Sector Disclosures Financial Servicessehingga dapat dipahami bahwa informasi-informasi yang disajikan dalam laporan keberlanjutan telah sesuai dengan rencana keberlanjutan perusahaan di masa depan. 


\section{Menentukan tingkat signifikansi dari isu keberlanjutan yang telah teridentifikasi dengan menggunakan kriteria yang telah ditentukan}

Tingkat signifikansi dari isu-isu keberlanjutan yang bersifat material dapat ditentukan dari matriks materialitas yang terdapat pada sampel laporan keberlanjutan perusahaan. Informasi-informasi yang memiliki tingkat signifikansi tinggi (informasi yang bersifat material) dapat diketahui dengan melihat kuadran pada matriks materialitas informasi. Informasi-informasi yang terdapat pada kuadran high atau dengan dampak yang tinggi terhadap perusahaan dan pemangku kepentingan perusahaan memiliki tingkat signifikansi yang tinggi.

Pada penentuan tingkat signifikansi ini dipergunakan matriks materialitas yang terdapat pada laporan keberlanjutan perusahaan yang dipergunakan sebagai sampel. Berdasarkan matriks materialitas maka dapat dikelompokkan informasi-informasi yang bersifat material dalam laporan keberlanjutan industri perbankan yang dipergunakan sebagai sampel, yaitu

- Kinerja ekonomi

- Privasi nasabah

- Pelabelan produk dan jasa

- Portofolio keuangan

- Anti korupsi dan pencegahan fraud

- Kesehatan dan keselamatan kerja

- Akses ke layanan perbankan

- Pendidikan dan pelatihan pegawai - Pemberdayaan masyarakat

\section{Mengidentifikasi dampak-dampak dari isu-isu keberlanjutan perusahaan terhadap kepentingan dari seluruh pemangku kepentingan perusahaan}

Pada tahap ini dilakukan identifikasi dampak dari isu-isu keberlanjutan yang material dalam laporan keberlanjutan sampel terhadap kepentingan dari seluruh pemangku kepentingan perusahaan. Semua manajemen perusahaan yang laporan keberlanjutannya dijadikan sampel telah melakukan pengelompokan pemangku kepentingan perusahaan. Manajemen PT BNI telah melakukan pengelompokan terhadap pemangku kepentingan perusahaan. Pemangku kepentingan perusahaan terdiri dari (1) nasabah, (2) investor/pemegang saham, (3) pegawai, (4) serikat pekerja, (5) pemerintah dan OJK, (6) pemasok, (7) organisasi bisnis, (8) organisasi masyarakat, dan (9) media. Manajemen PT Bank Danamon telah melakukan pengelompokan terhadap kelompok pemangku kepentingan perusahaan. Kelompok pemangku kepentingan tersebut, yaitu (1) nasabah, (2) karyawan, (3) pemerintah dan regulator, (4) pemegang saham dan investor, (5) media, dan (6) LSM dan masyarakat umum. Manajemen PT Bank CIMB Niaga dalam laporan keberlanjutannya menyatakan bahwa kelompok pemangku kepentingan perusahaan adalah (1) nasabah, (2) pemegang saham/investor, (3) regulator, (4) pemasok, (5) karyawan, (6) serikat pekerja, dan (7) masyarakat umum. Manajemen PT Bank Maybank Indonesia telah mengelompokkan pemangku kepentingan perusahaan ke dalam beberapa kelompok, yaitu (1) nasabah, (2) masyarakat dan LSM, (3) karyawan, (4) serikat pekerja, (5) pemerintah dan regulator (OJK), dan (6) media. Manajemen PT Bank BPD Jawa Tengah telah melakukan pengelompokan pemangku kepentingan perusahaan, yaitu (1) pemegang saham/komisaris, (2) nasabah, (3) pegawai, (4) mitra bisnis/pemasok, (5) pemerintah/pembuat kebijakan, dan (6) organisasi kemasyarakatan. Bagan dari kelompok pemangku kepentingan dalam industri perbankan, yaitu 


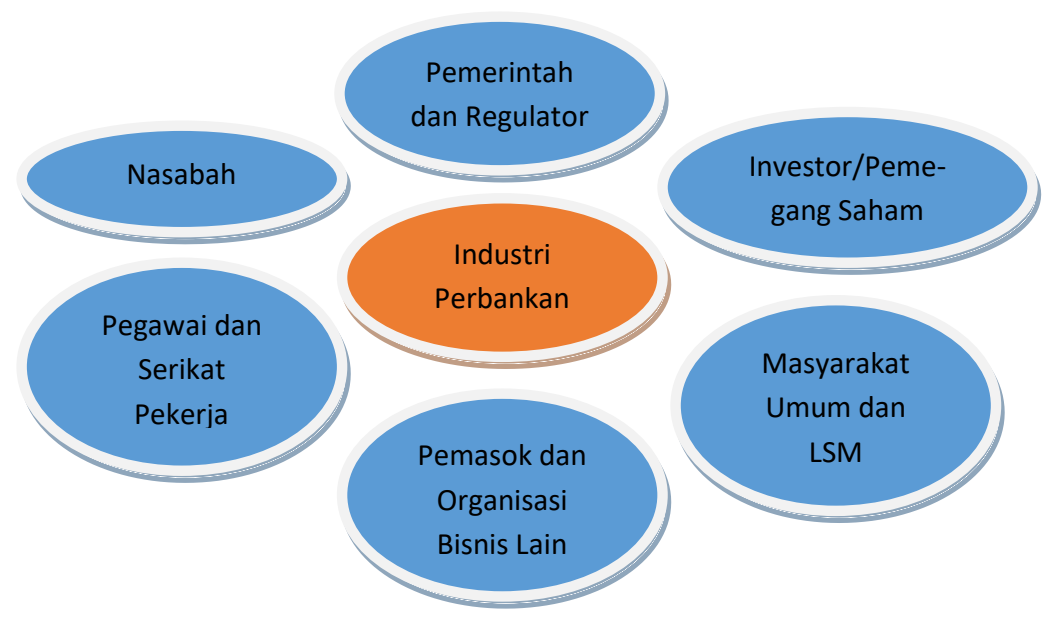

Gambar 9. Kelompok pemangku kepentingan industri perbankan

Identifikasi dampak ini dapat dilakukan dengan menghubungkan antara informasi yang bersifat material dengan kepentingan dari kelompok pemangku kepentingan perusahaan. Kinerja ekonomi perseroan tentu saja berdampak pada kepentingan investor atau pemegang saham. Manajemen perusahaan sebagai agent harus mampu bertindak mengelola sumber daya perusahaan agar memenuhi harapan dari investor yang bertindak sebagai principal. Informasi mengenai privasi nasabah, akses ke layanan perbankan, dan informasi mengenai produk perbankan tentu saja berdampak pada kepentingan nasabah. Informasi mengenai pendidikan dan pelatihan pegawai akan berdampak pada kepentingan karyawan. Dalam konteks ini kita dapat memahami bahwa pemangku kepentingan perusahaan dapat berfokus hanya pada informasi-informasi yang akan berdampak besar bagi kepentingan mereka. Manetti (2011) berpendapat bahwa pemangku kepentingan perusahaan dapat dilibatkan untuk menentukan informasi yang bersifat material. Proses stakeholder engagement dapat menjadi langkah awal untuk menentukan informasi-informasi yang material dan tingkat relevansi informasi-informasi tersebut bagi pemangku kepentingan perusahaan.

\section{Penyusunan Peta Materialitas Informasi Laporan Keberlanjutan Industri Perbankan}

Secara umum model peta materialitas informasi yang disusun disesuaikan dengan analisis yang telah dilakukan dan berisi informasi-informasi material dalam konteks laporan keberlanjutan perusahaan yang termasuk dalam industri perbankan. Konsep dasar dalam penyusunan peta materialitas informasi ini didasarkan pada pemahaman bahwa tingkat materialitas informasi dalam laporan keberlanjutan perusahaan memiliki hubungan dengan tingkat dampak berpengaruhnya informasi tersebut terhadap kepentingan dari pemangku kepentingan perusahaan. Dalam model peta materialitas informasi ini akan disusun peta yang menghubungkan antara jenis informasi dengan tingkat dampak yang dapat dirasakan oleh pemangku kepentingan perusahaan. Dalam pemodelan peta juga akan dimasukkan tingkat dampak yang berpengaruh terhadap kepentingan pemangku kepentingan industri perbankan dimana tingkat dampak dibedakan menjadi tiga jenis, yaitu low, medium, dan high. Tingkat dampak low dapat diartikan bahwa informasi material tersebut berdampak kecil pada kepentingan pemangku kepentingan perusahaan dan begitu juga dengan pengertian tingkat dampak 
medium dan high. Dasar dalam penyusunan peta materialitas informasi ini adalah didasarkan pada materiality map yang dikembangkan oleh SASB (Sustainability Accounting Standards Board). Dalam konsep SASB materiality map terdapat informasi-informasi material yang berlaku bagi masing-masing industri. Dalam materiality map yang dikembangkan SASB kita dapat melihat informasi material berdasarkan basis industrinya. Model dari peta materialitas informasi dalam industri perbankan yang disusun dalam penelitian ini, yaitu

Tabel Peta Materialitas Informasi Industri Perbankan

\begin{tabular}{|c|c|c|c|c|c|c|c|}
\hline \multirow{2}{*}{$\begin{array}{c}\text { Informasi } \\
\text { Material } \\
\text { dalam Industri } \\
\text { Perbankan }\end{array}$} & \multicolumn{7}{|c|}{ Pemangku Kepentingan Industri Perbankan } \\
\hline & Nasabah & $\begin{array}{c}\text { Pemerintah/ } \\
\text { Regulator }\end{array}$ & Investor & $\begin{array}{c}\text { Pegawai/ } \\
\text { Serikat } \\
\text { Pekerja }\end{array}$ & $\begin{array}{l}\text { Pemasok/ } \\
\text { Organisasi } \\
\text { Bisnis } \\
\text { Lain } \\
\end{array}$ & $\begin{array}{c}\text { Masyarakat } \\
\text { Umum }\end{array}$ & LSM \\
\hline $\begin{array}{c}\text { Kinerja } \\
\text { Ekonomi }\end{array}$ & $>$ & $\bullet$ & $\bullet$ & $\bullet$ & $\bullet$ & $>$ & $>$ \\
\hline $\begin{array}{c}\text { Privasi } \\
\text { Nasabah }\end{array}$ & $\bullet$ & $\bullet$ & $>$ & $\checkmark$ & $\checkmark$ & $\bullet$ & $\checkmark$ \\
\hline $\begin{array}{c}\text { Pelabelan } \\
\text { Produk/Jasa }\end{array}$ & $\bullet$ & $\bullet$ & $>$ & $>$ & $>$ & $>$ & $>$ \\
\hline $\begin{array}{l}\text { Portofolio } \\
\text { Keuangan }\end{array}$ & $\bullet$ & $\bullet$ & $>$ & $>$ & $>$ & $\checkmark$ & $\checkmark$ \\
\hline $\begin{array}{c}\text { Pendidikan } \\
\text { dan Pelatihan }\end{array}$ & $\checkmark$ & $\bullet$ & $\bullet$ & $\bullet$ & $>$ & $\checkmark$ & • \\
\hline $\begin{array}{l}\text { Anti Korupsi } \\
\text { dan } \\
\text { Pencegahan } \\
\text { Fraud }\end{array}$ & $\bullet$ & $\bullet$ & $\bullet$ & $\bullet$ & $>$ & $\bullet$ & • \\
\hline $\begin{array}{c}\text { Kesehatan dan } \\
\text { Keselamatan } \\
\text { Kerja }\end{array}$ & • & $\bullet$ & $\bullet$ & $\bullet$ & $D$ & $>$ & $\checkmark$ \\
\hline $\begin{array}{l}\text { Akses ke } \\
\text { Layanan } \\
\text { Perbankan }\end{array}$ & • & • & $\sqrt{ }$ & $\checkmark$ & $\checkmark$ & $\bullet$ & $>$ \\
\hline $\begin{array}{c}\text { Informasi } \\
\text { Mengenai } \\
\text { Produk dan } \\
\text { Layanan } \\
\end{array}$ & $\bullet$ & $\bullet$ & $>$ & $\checkmark$ & $\checkmark$ & $\bullet$ & • \\
\hline $\begin{array}{c}\text { Pemberdayaan } \\
\text { Masyarakat }\end{array}$ & $>$ & • & $>$ & $\checkmark$ & $>$ & • & $\bullet$ \\
\hline
\end{tabular}

Keterangan tingkat dampak:

- : High

$>$ : Medium

$\checkmark$ : Low

Pada penyusunan peta materialitas ini, satu jenis informasi dapat material bagi banyak pemangku kepentingan perusahaan. Informasi mengenai kinerja perusahaan dapat 
material pemerintah/regulator, investor, dan pegawai. Pemerintah dan OJK memiliki kepentingan terkait dengan kinerja ekonomi perbankan, utamanya pada bank-bank BUMN dan BPD. Investorpun turut pula selalu melihat kinerja ekonomi perseroan utamanya dalam hal investasi yang telah dilakukan. Pegawai memiliki kepentingan yang berbeda dimana kinerja ekonomi perseroan dapat dijadikan salah satu tolok ukur dari kinerja dan kualitas sumber daya manusia. Informasi mengenai anti korupsi dan pencegahan fraud dalam internal perseroan tentu saja sangat material bagi seluruh pemangku kepentingan perusahaan. Hal ini tentu sesuai dengan pendapat Kolk (2008) bahwa tata kelola perusahaan sangat erat kaitannya dengan keberlanjutan perusahaan. Jika manajemen perusahaan dalam mengelola perusahaan mampu mencegah korupsi dan fraud tentu saja tujuan dari keberlanjutan perusahaan akan dapat tercapai. Pengisian peta materialitas ini sangat ditentukan oleh penilaian yang dilakukan sendiri oleh manajemen perseroan. Manajemen perseroan harus mengetahui siapa saja kelompok pemangku kepentingan perusahaan dan menentukan aspek-aspek material apa yang berpengaruh terhadap kelompok pemangku kepentingan tersebut. Secara umum kelompok pemangku kepentingan perusahaan dapat dibagi menjadi dua, yaitu pemangku kepentingan yang berada di internal perusahaan dan pemangku kepentingan yang berada di eksternal perusahaan. Seharusnya manajemen perusahaan dapat memberikan informasi yang lengkap pada seluruh pemangku kepentingan perusahaan. Ini juga merupakan pertanggungjawaban moral manajemen perusahaan dalam mengelola perusahaan kepada pemangku kepentingan perusahaan. Berdasarkan hal ini maka fungsi dari laporan keberlanjutan perusahaan sebagai media komunikasi antara manajemen perseroan dengan pemangku kepentingan perusahaan akan dapat tercapai.

Zhou (2011) menyatakan bahwa banyaknya pemangku kepentingan perusahaan akan menunjukkan kepentingan yang berbeda-beda dan tentu saja untuk mengakomodir hal ini manajemen perusahaan harus melaporkan banyak data. Konsekuensinya adalah waktu dan biaya yang dikeluarkan menjadi lebih besar, dengan kemungkinan tingkat efektivitas informasi tersebut kecil. Identifikasi terhadap materialitas informasi dan dampaknya terhadap pemangku kepentingan perusahaan dimaksudkan agar manajemen perusahaan dapat berfokus pada informasi-informasi yang memang diperlukan oleh pemangku kepentingan perusahaan. Dalam konteks ini maka pemangku kepentingan perusahaan akan mendapatkan informasi yang diperlukan dalam laporan keberlanjutan perusahaan sehingga efektivitas informasi tersebut menjadi tinggi. Pendapat lain terkait materialitas informasi disampaikan oleh Eccles et. al., (2012) yang menyatakan bahwa penentuan materialitas informasi sebaiknya dilakukan berdasarkan basis industri perusahaan. Pendapat Eccles et. al., (2012) ini mendukung sebuah konsep yang menyatakan bahwa konsep keberlanjutan setiap perusahaan berbeda-beda tergantung dengan industri dimana perusahaan itu berada. Informasi yang material dalam industri manufaktur tentu berbeda dengan informasi yang material dalam industri perbankan. Tentu saja juga hal ini dipengaruhi oleh pemangku kepentingan perusahaan yang berbeda-beda untuk setiap industri.

\section{Simpulan, Implikasi, Keterbatasan, dan Saran \\ Simpulan}

Hasil penelitian ini menemukan bahwa dalam kurun waktu tahun 2014 sampai tahun 2016 informasi yang bersifat material dalam laporan keberlanjutan industri perbankan adalah (1) kinerja ekonomi, (2) privasi nasabah, (3) pelabelan produk atau jasa, (4) portofolio keuangan, (5) pendidikan dan pelatihan pegawai, (6) anti korupsi 
dan pencegahan fraud, (7) kesehatan dan keselamatan kerja, (8) akses ke layanan perbankan, (9) informasi mengenai produk dan layanan, dan (10) pemberdayaan masyarakat. Hasil penelitian ini memberikan hasil yang secara umum sama dengan hasil penelitian GRI dan RobecoSAM tahun 2015 dimana informasi yang material bagi industri perbankan adalah risk management (manajemen resiko), corporate governance (tata kelola perusahaan), human capital management (manajemen sumber daya manusia), dan business ethic (etika bisnis). Meskipun kembali lagi kita harus memahami bahwa perbedaan informasi yang material bagi industri perbankan dapat terjadi dikarenakan berbagai faktor yang dapat berpengaruh. Dalam konteks ini maka kita dapat memahami bahwa materialitas informasi dalam laporan keberlanjutan perusahaan ditentukan oleh karakteristik perusahaan, jenis industri, dan karakteristik pemangku kepentingan perusahaan. Semua laporan keberlanjutan yang dijadikan sampel telah menyajikan informasi kinerja keuangan, kinerja sosial, dan kinerja lingkungan dengan sangat baik. Hal ini tentu saja dapat memunculkan sebuah asumsi bahwa nantinya laporan keberlanjutan perusahaan ini akan menjadi dasar bagi sebuah konsep laporan terintegrasi (integrated reporting). Konsep pelaporan terintegrasi nantinya diharapkan dapat menjadi konsep baru yang dimunculkan dari konsep pelaporan keberlanjutan. Simpulan dalam penelitian ini senada dengan pernyataan dalam laporan Ernst \& Young (2015) yang menyatakan bahwa pelaporan keberlanjutan akan terus berkembang dan di masa depan kita berharap akan terdapat kombinasi yang baik antara pelaporan keuangan dengan pelaporan non keuangan sebagai bagian untuk mengintegrasikan konsep keberlanjutan pada aktivitas bisnis perusahaan.

\section{Implikasi}

Penelitian ini diharapkan dapat memberikan kontribusi bagi pengembangan kegiatan pelaporan keberlanjutan perusahaan di Indonesia. Hasil penelitian ini dapat memberikan pemahaman baru mengenai informasi yang bersifat material pada laporan keberlanjutan perusahaan. Secara langsung hasil penelitian ini memberikan informasiinformasi yang bersifat material yang harus diungkapkan dalam laporan keberlanjutan industri perbankan di Indonesia. Informasi-informasi yang bersifat material ini sangat penting untuk diungkapkan oleh perbankan kepada pemangku kepentingannya. Bagaimana pun juga salah satu fungsi dalam pelaporan keberlanjutan adalah menjadi alat komunikasi kepentingan manajemen industri perbankan dengan seluruh pemangku kepentingan dalam konteks keberlanjutan. Implikasi lain dari hasil penelitian ini adalah diharapkan adanya peningkatan kualitas informasi non finansial (informasi sosial dan informasi lingkungan) yang disampaikan oleh manajemen kepada seluruh pemangku kepentingan perusahaan. Ketika manajemen perusahaan meningkatkan kualitas informasi non finansialnya maka akan diperoleh dua keuntungan, yaitu (1) kualitas informasi finansial dan informasi non finansial akan sama sehingga pemangku kepentingan perusahaan dapat menilai perusahaan secara komprehensif dan (2) pemangku kepentingan dapat mengambil keputusan dengan baik sesuai dengan kualitas informasi finansial dan informasi non finansial. Bagaimanapun juga harus disadari bahwa salah satu tujuan manajemen perusahaan melakukan pelaporan adalah untuk memberikan informasi kepada seluruh pemangku kepentingan perusahaan sehingga pada akhirnya pemangku kepentingan perusahaan dapat mengambil keputusan yang tepat. 


\section{Keterbatasan Penelitian}

Penulis menyadari bahwa dalam penelitian ini masih terdapat beberapa keterbatasan. Keterbatasan pertama adalah bahwa penelitian ini dilakukan tanpa melakukan observasi langsung untuk melihat kondisi perusahaan. Keterbatasan ini akan menghasilkan dampak bahwa peneliti melihat kondisi nyata perusahaan dari informasiinformasi yang terdapat dalam laporan keberlanjutan perusahaan. Secara tidak langsung peneliti tidak dapat melihat secara objektif kondisi aktual perusahaan dan hanya didasarkan pada informasi-informasi yang terdapat pada laporan keberlanjutan perusahaan. Dapat dikatakan pula bahwa penilaian peneliti masih sangat subjektif dalam pembahasan. Keterbatasan kedua adalah peneliti tidak dapat mengidentifikasi seluruh pemangku kepentingan perusahaan. Dampak dari keterbatasan kedua ini adalah peneliti tidak dapat memastikan secara langsung dampak aktivitas bisnis perusahaan terhadap pemangku kepentingan perusahaan. Keterbatasan kedua ini juga mengakibatkan peneliti tidak dapat melihat reaksi pemangku kepentingan perusahaan yang terkait dengan informasi yang material. Keterbatasan ketiga adalah terkait dengan sampel laporan keberlanjutan perusahaan yang masih sedikit untuk mewakili industri perbankan. Hasil penelitian ini mungkin saja dapat menghasilkan informasi material yang lebih kompleks bila sampel laporan keberlanjutan perusahaan dapat ditambah.

\section{Saran}

Penulis berharap akan banyak topik-topik baru dalam penelitian yang terkait dengan proses pelaporan keberlanjutan atau laporan keberlanjutan perusahaan. Saran pertama yang dapat diberikan adalah penelitian berikutnya dapat melakukan observasi ke perusahaan secara langsung dan membandingkan hasil observasi dengan informasi yang terdapat pada laporan keberlanjutan perusahaan. Dengan cara ini maka hasil pembahasan penelitian akan menjadi semakin lebih objektif. Saran kedua yang dapat penulis sampaikan untuk penelitian berikutnya adalah melakukan wawancara kepada manajemen perusahaan dan pemangku kepentingan perusahaan. Wawancara kepada manajemen untuk memastikan siapa sajakah kelompok pemangku kepentingan perusahaan dan wawancara kepada pemangku kepentingan perusahaan untuk mendapatkan informasi mengenai dampak aktivitas bisnis perusahaan terhadap kepentingan pemangku kepentingan perusahaan. Wawancara terhadap pemangku kepentingan perusahaan juga untuk mendapatkan gambaran mengenai reaksi pemangku kepentingan perusahaan mengenai informasi material pada laporan keberlanjutan perusahaan. Saran ketiga yang dapat diberikan adalah penelitian berikutnya dapat mempergunakan sampel laporan keberlanjutan pada industri perbankan yang tidak hanya mengikuti kompetisi ISRA. Dengan demikian maka peta materialitas yang disusun akan lebih komprehensif. Penelitian berikutnya dapat melanjutkan penelitian ini dengan melakukan penyusunan peta materialitas informasi laporan keberlanjutan pada semua jenis industri. Dengan adanya peta materialitas ini diharapkan manajemen perusahaan akan terbantu untuk menentukan jenis-jenis informasi yang material yang sesuai dengan karakteristik industrinya. Nantinya akan dapat diperbandingkan informasi-informasi yang bersifat material dalam lintas industri. Hal ini tentu akan dapat membantu bagi manajemen perusahaan yang akan memulai untuk menyusun laporan keberlanjutan perusahaan. 


\section{Ucapan Terima Kasih}

Penulis mengucapkan terimakasih sebesar-besarnya kepada Ketua Jurusan Akuntansi Program S1, Fakultas Ekonomi, Universitas Pendidikan Ganesha yang telah memberikan kesempatan kepada penulis untuk melaksanakan penelitian ini. Penulis juga mengucapkan terimakasih kepada rekan-rekan staf pengajar yang telah memberikan kontribusi sehingga penelitian ini dapat terselesaikan dengan baik. Tidak lupa penulis juga menyampaikan terimakasih kepada rekan-rekan yang mengikuti pelatihan CSRS dan CSRA Batch Universitas Brawijaya, Malang atas kesempatan memperoleh ilmu yang baru. Penulis berharap melalui artikel penelitian ini dapat memberikan manfaat yang besar bagi pembaca dan dapat memberikan kontribusi bagi pengembangan pelaporan keberlanjutan di Indonesia.

\section{DAFTAR PUSTAKA}

Brown, H.S., M. de Jong dan D.L. Levy. 2009. Building institutions based on information disclosure: lessons from GRI's sustainability reporting. Journal of Cleaner Production. Vol. 17. Pp. 571-580.

Eccles, R. G., M. P. Krzus, J. Rogers dan G. Serafeim. 2012. The need for sector-specific materiality and sustainability reporting standards. Journal of Applied Corporate Finance. Vol. 24. No. 2. Pp. 65-71.

Ernst \& Young. 2015. Materiality and Sustainability Disclosure Key Insights from the Singapore Exchange Top 50. Singapore: Ernst \& Young.

GRI. 2013. GRI G4 Sector Disclosures Financial Services. Amsterdam: GRI.

GRI \& RobecoSAM. 2015. Defining materiality: what matters to reporters and investors. Amsterdam: GRI.

Khan, M., G. Serafeim, dan A. Yoon. 2016. Corporate sustainability: First evidence on materiality. The accounting review. Vol. 91. No. 6. Pp. 1697-1724.

Kolk, A. 2008. Sustainability, accountability and corporate governance: exploring multinationals' reporting practices. Business Strategy and the Environment. Vol. 17. No. 1. Pp. 1-15.

Manetti, G. 2011. The quality of stakeholder engagement in sustainability reporting: empirical evidence and critical points. Corporate Social Responsibility and Environmental Management. Vol. 18. No. 2. Pp. 110-122.

Naraduhita, D.C. dan T. Sawarjuwono. 2012. Corporate social responsibility: upaya memahami alasan dibalik pengungkapan CSR bidang pendidikan. Jurnal Akuntansi dan Auditing. Vol. 8. No. 2. Pp. 95-108.

Nuryaman. 2013. The effect of corporate social responsibility activities on profitability and stock price (studies on the companies listed on Indonesia Stock Exchange). $4^{\text {th }}$ International Conference on Business and Economic Research ( $4^{\text {th }}$ ICBER 2013). Proceeding. Pp. 756-769. 
Qureshi, N. Z., D. Kulshrestha, dan S. B. Tiwari. 2012. Environmental accounting and reporting: an essential component of business strategy. Asian Journal of Research in Banking and Finance. Vol. 2. No. 4. Pp. 85-95.

Retno, R. D. dan D. Priantinah. 2012. Pengaruh good corporate governance dan pengungkapan corporate social responsibility terhadap nilai perusahaan (studi empiris pada perusahaan yang terdaftar di Bursa Efek Indonesia periode 20072010). Jurnal Nominal. Vol. 1. No. 1. Pp. 84-103.

Sangle, S. 2010. Empirical analysis of determinants of adoption of proactive environmental strategies in India. Business Strategy \& the Environment. Vol. 19. No. 1. Pp. 51-63.

Soetedjo, Soegeng. 2009. Pembahasan Pokok-Pokok Pikiran Teori Akuntansi Vernon Kam. Surabaya: Airlangga University Press.

Zhou, Y. 2011. Materiality approach in sustainability reporting: applications, dilemmas, and challenges. $1^{\text {st }}$ World Sustainability Forum, 1-30 November 2011. 